NBER WORKING PAPER SERIES

SEIGNIORAGE, INFLATION,
AND REPUTATION

Hersche1 I. Grossman

John B. Van Huyck

Working Paper No. 1505

NATIONAL BUREAU OF ECONOMIC RESEARCH

1050 Massachusetts Avenue

Cambridge, MA 02138

November 1984

The National Science Foundation has supported Grossman's work. The Social Science Research Council and a Citicorp Graduate Fellowship have supported Van Huyck's work. The research reported here is part of the NBER's research program in Financial Markets and Monetary Economics and project in Government Budget. Any opinions expressed are those of the authors and not those of the National Bureau of Economic Research. 
NBER Working Paper 1505

November 1984

\author{
Seigniorage, Inflation, \\ and Reputation
}

\title{
ABSTRACT
}

This paper derives a reputational equilibrium for inflation in a model in which the government obtains valuable seigniorage by issuing fiat money in exchange for real resources. One insightful result is that, with contemporaneous perception of actual government behavior and immediate adjustment of real cash balances to new information, the Friedman elasticity solution for maximal seigniorage is the reputational equilibrium. More generally, the analysis shows that the objective of maximal seigniorage produces an equilibrium inflation rate equal either to a generalization of the Friedman elasticity solution or to the rate at which the government discounts future seigniorage adjusted for the growth rate, whichever is larger. Thus, the model formalizes the conjecture that episodes of inflation rates in excess of the Friedman solution are attributable to high discount rates for future seigniorage. Adding aversion to high expected inflation to the model, this analysis also rationalizes the observation that inflation rates are usually less than Friedman's elasticity solution.

Herschel Grossman Department of Economics Brown University

Providence, RI 02912
John Van Huyck Department of Economics Brown University Providence, RI 02912 
A useful positive theory of inflation not only must explain why governments commonly expand the stock of fiat money at an inflationary rate, but must account also for wide variations in inflation over time and place. The observation that governments desire seigniorage, which they obrain by issuing fiat money in exchange for real resources, directs attention to a potentially important element in such a theory. The importance of seigniorage in public finance extends back to ancient times. Fischer (1982) presents data for 120 countries that summarizes the importance of seigniorage in recent years. A convenient way to begin to analyze seigniorage as a motivation for inflation is to ask the following question: If a government wanted to maximize the present value of its flow of seigniorage, at what rate would it issue fiat money?

The essential analytical problem in answering this question concerns the formulation of the government's choice set, especially as it involves the determination of expected inflation and the relation between expected inflation and actual money issue. An old strategy--see, for example, Friedman (1942, 1971)--treats the expected inflation rate, Ep, as a policy variable, and assumes that the government issues money at the rate that validates its choice of Ep. Using this framework, Friedman obtains his elasticity formula. specifically, if the elasticity of the stock demand for real cash balances with respect to the expected inflation rate is $-E p / h$, where $h$ is a positive parameter, a government seeking to maximize seigniorage would set Ep equal to $h-g$, where $g$ is the growth rate of cash 
balance demand, and would issue money at the rate, h. This policy would produce an actual inflation rate, $\mathrm{p}$, equal to $\mathrm{h}-\mathrm{g}$, and, for the case of $g$ equal to zero, would imply an elasticity of demand equal to minus unity.

Estimates of the inflation rate that would correspond to the Friedman elasticity solution for maximal-seigniorge differ widely. For example, for the case of g equal to zero, Friedman (1971) suggests a range of 58 to 508 per annum, whereas Cagan (1956) suggests a range of 118 to 448 per month and Barro (1972), using an explicit inventory-theoretic analysis of money demand, calculates an average value of about 1508 per month. In any event, it seems clear that actual inflation rates are usually less than the Friedman elasticity solution, but that in some historical cases the actual inflation rate has exceeded the Friedman answer.

An easy way to extend the Friedman framework to account for inflation rates, less than the Friedman elasticity solution is to assume that most governments, for whatever reason, are averse to high expected inflation rates and, hence, forego maximal seigniorage. Inflation rates in excess of the Friedman elasticity solution are a bigger problem for this analysis. Friedman (1971) suggests that such episodes reflect unusually high discount rates for future seigniorage, which induce governments to obtain more seigniorage now at the expense of less seigniorage later by taking advantage of lags in the response of real cash balances to accelerated money issue. Friedman, however, considers neither the possiblity that inflationary 
expectations would anticipate this potential government behavior nor the associated implications of high discount rates for an inflationary equilibrium.

More recent analytical developments derive from related reservations about the treatment of expectations in the Friedman framework. Calvo (1978) stresses that the Friedman elasticity solution describes policies that are not time consistent and, hence, would be relevant only if a government could bind itself to fulfill its commitment regarding future inflation rates. In reality, such an irrevocable commitment is not feasible. Indeed, it would seem to contradict the concept of sovereignty. Accordingly, it is wrong to treat inflationary expectations as a policy variable.

Calvo formalizes this limitation on policy by assuming that the government regards inflationary expectations as given and not subject to its choice or influence. Using this framework, Calvo finds that a desire to maximize seigniorage would lead to money issue at the fastest physically possible rate. This policy would produce an inflation rate, $\bar{p}$, which is presumably much larger than $\mathrm{h}-\mathrm{g}$. Moreover, if the given inflationary expectations are rational, the Calvo analysis implies that expected inflation would equal $\bar{p}$, and that both the real stock of cash demanded and realized seigniorage would be small, at least relative to the outcome under the Friedman elasticity solution.

Although the infeasibility of policy commitments would seem to be a fundamental consideration in the analysis of seigniorage, Calvo's alternative to Friedman's analysis clearly is not 
descriptively realistic. Even in hyperinflations, governments rarely issue money at the fastest physically possible rate. Moreover, in the Calvo framework, aversion to high expected inflation cannot explain low inflation because the government takes inflationary expectations as given. In response to this problem, Barro (1983) assumes that governments are averse to inflation, whether expected or not, and he derives a variation on the Calvo result in which the inflation rate is less than $\bar{p}$ by an amount that depends on the strength of this aversion relative to the desire for seigniorage. As Barro recognizes, however, a weakness in his theory is the lack of a convincing rationale for strong aversion to unexpected inflation.

The present paper reconsiders the maximal seigniorage question within a more general model of the determination of expected inflation and the relation between expected inflation and actual money issue. In this model, inflationary expectations are not a proximate policy variable as in the Friedman framework, but are also not independent of the choice of money issue as in the Calvo/Barro framework. Instead, the model assumes that policy actions and inflationary expectations are linked through the government's reputation. Given this linkage, the Calvo/Barro outcome, although time consistent, would be myopic and, consequently, would not be the actual result of a foresighted government's desire to maximize the present value of its seigniorage, even if the government cannot explicitly bind itself to fulfill commitments. The answer to the maximal-seigniorage question instead takes the form of a reputational equilibrium in which policy is both time consistent and foresighted. 
In what follows, section I develops the basic analytical framework. Sections II and III replicate Friedman's analysis and Calvo's analysis. Section IV formulates the model of reputation and derives the reputational equilibrium. Finally, section $\mathrm{V}$ summarizes the main properties of this equilibrium and discusses some extensions that would characterize a full positive theory of inflation.

I. Analytical Framework

The maximal-seigniorage question assumes that the government's objective for period $t$ is to maximize

(1) $\quad s_{t}=\sum_{i=0}^{\infty} \exp (-r r i) s_{t+i}$

where $S_{t}$ is the present value of current and future seigniorage, $s_{t+i}$ is the seigniorage obtained in period $t+i, r$ is the annual rate at which the government discounts future seigniorage, and $\tau$ is the length of a period in units of years. The government's proximate control variable is current fiat money issue, and its objective implies that it takes account of the effects of current money issue on both current seigniorage and future seigniorage. The analysis assumes that the fastest physically possible rate of money issue, although finite, is very large.

As the analysis below shows, an important potential explanation for differences in inflation rates is that different governments have different discount rates. A dramatic example is that a government fighting a major war, especially one that 
threatened its survival, would be likely to have a relatively high discount rate. For simplicity, the present analysis treats the discount rate as constant over time, although the same results would also apply if the discount rate followed a random walk. In general, correctly allowing for the possibility of changes in the discount rate over time would present a more ambitious modelling problem than does the present comparison of the implications of different constant discount rates. (For more on this issue, see Grossman (1984)).

Assuming that fiat money is produced at zero cost, seigniorage in period $t$ is the purchasing power of the government's current fiat money issue. Current seigniorage is expressable equivalently as an increasing function of the current inflation rate and current real cash balances. Specificially,

$$
s_{t}=\frac{M_{t}-M_{t-1}}{P_{t}} \equiv \frac{M_{t}}{P_{t}}-\exp \left(-\tau p_{t}\right) \frac{M_{t-1}}{P_{t-1}},
$$

where $M_{t}$ is the stock of fiat money is period $t, P_{t}$ is the price level in period $t$, and $p_{t}$ is the annual inflation rate in period $t$, i.e. $(1 / \tau) \ln \left(P_{t} / P_{t-l}\right)$. Equation (2) implies that the analysis can formulate the government's problem either as the choice of current money issue given a constraint on the path of the price level or as the choice of the current inflation rate given a constraint on the path of real money balances. The latter formulation is algebraically more convenient. Let $\bar{p}$ denote the annual inflation rate that corresponds to the fastest physically possible rate of money issue. 
To model the constraint on real cash balances, assume that the demand for real cash balances depends logarithmically on the expected inflation rate, and that the price level adjusts to equate actual real cash balances to the quantity demanded. Thus, $P_{t}$ satisfies

$$
\frac{M_{t}}{P_{t}}=\exp \left(\tau g t-\frac{E_{t-1} p_{t+1}}{h}\right)
$$

where $E_{t-1} p_{t+1}$ is the public's expectation of $p_{t+l}$ conditional on its perception of government behavior formed in period $t-l$, and $g$ is an annual growth rate that captures the effects of all other factors, e.g. population and income growth and developments in financial technology, that influence the demand for real cash balances. The analysis treats $g$ and the parameter $h$ as fixed and focuses on inflationary expectations as the link between policy, i.e. the inflation rate, and real cash balances. (Nichols (1974) analyses the use of financial regulations to influence parameters like $\mathrm{g}$ and $\mathrm{h} . \mathrm{l}$

This formulation of demand reflects the observation that the holders of real cash balances are atomistic agents who cannot individually influence the government behavior that produces inflation. Consequently, the demand for real cash balances does not incorporate any strategic elements, and the government plays what is analogous to a game against nature.

The assumption that the expectation relevant for current demand is based on a perception formed last period provides a simple way to model a lag in either the perception of actual 
government behavior or in the adjustment of real cash balances. In this analyses, the length of the adjustment lag determines $\tau$, the length of a single time period. Consideration of the effects of different values of $\tau$ reveals the significance of this lag.

Substituting equations (3) and (2) into equation (1) gives

$$
\begin{aligned}
S_{t}=\exp (\tau g t) & \sum_{i=0}^{\infty} \exp [-(r-g) \tau i]\left[\exp \left(\frac{-E_{t+i-1} p_{t+i+1}}{h}\right)\right. \\
& \left.-\exp \left(-\tau p_{t+i}-\tau g-\frac{E_{t+i-2} p_{t+i}}{h}\right)\right] .
\end{aligned}
$$

For constant values of inflation and inflationary expectations, $p$ and Ep, equation (4) becomes, given $r>g$,

$$
s_{t}=\exp \left(\tau g t-\frac{E p}{h}\right) \frac{l-\exp [-\tau(p+g)]}{1-\frac{\exp }{\tau}[-\tau(r-g)]} \text {. }
$$

The final component needed to complete the analytical framework is the determination of inflationary expectations. The analysis assumes that these expectations are based on the public's perception of the strategy that the government employs in attempting to maximize seigniorage. The different answers to the maximal-seigniorage question discussed in the following sections reflect differences in these strategies. 
II. Friedman's Analysis

Suppose that the government could commit itself irrevocably to a desired path of future inflation rates. Such a commitment would determine inflationary expectations. In this case, given the fixed nonstochastic structure of the model, the maximalseigniorage problem would amount to choosing Ep and $\mathrm{p}$ to maximize $S_{t}$ subject to the constraint that $p$ must equal $E p$. The critical values for this problem, obtained by replacing p by Ep in equation (5) and setting $\mathrm{dS}_{\mathrm{t}} / \mathrm{dEp}$ equal to zero, are

$$
p^{\prime}=E p^{\prime}=\frac{\ln (1+\tau h)}{\tau}-g
$$

Equation (6) is a generalization of the Friedman elasticity solution for the maximal seigniorage question. In the limit as $\tau$ goes to zero, $\mathrm{p}^{\prime}$ as given by equation (6) approaches $\mathrm{h}-\mathrm{g}$, which is exactly Friedman's answer. Substituting $p^{\prime}$ for both Ep and $p$ in equation (5) gives the value of $s_{t}$ implied by the commitment to the inflation rate $\mathrm{p}^{\prime}$.

(Auernheimer (1974) modified Friedman's analysis to deal with a nonsteady state in which the government need not verify the predetermined inflationary expectations of the initial period, but is committed to verify its choice of inflationary expectations for subsequent periods. Auernheimer's analysis would also apply to a government considering an initial issue of fiat money in exchange for real resources. Auernheimer derived the answer that the chosen value of $E p$ and $p$ for these subsequent periods would be somewhat less than $p^{\prime}$.) 


\section{Calvo's Analysis}

In reality, governments do not, and by their nature probably cannot, irrevocably commit themselves to specific inflation rates, or to any other policy rules. Indeed, the power to abrogate commitments without having to answer to a higher authority seems to be an essential property of sovereignty. Consequently, the Friedman strategy of treating inflationary expectations as a choice variable does not seem to provide a relevant analysis of seigniorage.

In developing an alternative to Friedman's strategy, Calvo supposes that, in addition to being incapable of credible commitments, the government ignores any effect that its current actions have on expectations of its future actions. In this case, given the fixed nonstochastic structure of the model, the maximal seigniorage problem would amount to choosing $p$ to maximize $S_{t}$, taking Ep as given. Equation (5) implies that the partial derivative $\partial S_{t} / \partial p$ is positive for all finite values of $p$. Thus, the critical value of $p$ for this problem is $\bar{p}$, which is the Calvo answer to the maximal-seigniorage question. It says that, if the government took inflationary expectations as given, the desire to maximize seigniorage would lead it to inflate at the fastest possible rate, independently of the path of inflationary expectations.

Assuming that the public correctly perceives how the government behaves, Ep in this case would also equal $\bar{p}$. Thus, substituting $\bar{p}$ for both Ep and $p$ in equation (5) gives the value of $s_{t}$ implied by the Calvo analyses. In the limit for an 
increasingly large value of $\bar{p}$, this value of $s_{t}$ approaches zero. Calvo's analysis shows that the result of taking inflationary expectations as given is "suboptimal" in the sense that any inflation rate less than $\bar{p}$ (but greater than $-g$ ) would yield more seigniorage, if the government could convince the public to expect that inflation rate. The Friedman answer $p^{\prime}$, is an example of such an inflation rate.

IV. Reputational Equilibrium

As discussed above, both theoretical considerations as well as the facts of inflationary experience suggest that the Friedman analysis and the Calvo analysis are each missing essential elements of the correct answer to the maximal-seigniorage question. To capture these elements, suppose that, although the government cannot directly control inflationary expectations by committing itself to future inflation rates, its current actions nevertheless influence expectations about its future actions. The linkage between current actions and expectations is the government's reputation. Given this linkage, a foresighted government would consider how its current actions affect its reputation and how its reputation affects its future ability to obtain seigniorage. Only a government that ignored its reputation would behave as in the Calvo analysis, but such behavior would be myopic.

To model the determination of the government's reputation, assume that the public presumes that the government's behavior will always be foresighted as long as the government has never 
acted myopically in the past. If, however, the government ever acts myopically, then the public withdraws this presumption and expects myopic behavior in the future. These assumptions imply that

(7) for $t<0, E_{t-1} p_{t+1}=p^{*}$ and

$$
\begin{aligned}
& \text { for } t>0 \text {, either } E_{t-1} p_{t+1}=p^{*} \\
& \quad \text { if } p_{t-j}=p^{*} \text { for all } j=1 \ldots t \\
& \text { or } E_{t-1} p_{t+1}=\bar{p} \text { otherwise, }
\end{aligned}
$$

where the initial issue of fiat money is in period $t=-1$ (making $p_{0}$ the first observation of inflation) and $p^{*}$ is the inflation rate that a foresighted seigniorage maximizing government would choose. Given the fixed nonstochastic structure of the model, $p^{*}$ is independent of $t$.

The essential properties of this model of reputation are that private agents are backward looking in determining the expected mode of government behavior, foresighted or myopic, but are forward looking in determining the expected inflation rate. The potential loss of reputation for being foresighted creates the distinction between foresighted and myopic behavior and, also, by penalizing myopic behavior with a sharp reduction in the demand for real cash balances, provides an incentive for foresighted behavior. This potential penalty emerges automatically from the actions of individual, atomistic holders of cash balances, who form inflationary expectations according to 
equation (7). The potential penalty does not require a willful enforcement decision by members of the public. This property reflects the observation that the government plays what is analogous to a game against nature. (A possible extension in this model of reputation might include assumptions about actions that a government could take in order to regain a lost reputation.)

Given this model of reputation, the problem for a foresighted seigniorage-maximizing government is to choose $p_{t}$, as part of an implicit program $\left\{p_{t+i}\right\}_{i=0}^{\infty}$, so as to maximize $S_{t}$ ' subject to equation (7). This choice establishes a reputational equilibrium in which, if the government validates inflationary expectations, the present value of seigniorage is at least as large as it would be if the government were to attempt to produce a temporarily large flow of seigniorage by making the inflation rate higher than the public expects. Thus, in the reputational equilibrium, a truly foresighted government always validates inflationary expectations by setting $p_{t}$ equal to $\mathrm{p}^{*}$, and thereby always keeps its good reputation.

The inflation rate $\mathrm{p}^{*}$, accordingly, is in the set of values of $p$ that could be reputational equilibria. Moreover, it is the member of this set that produces the largest value of $s_{t}$ for all $t=0 \ldots \infty$. The analytical problem is to determine the value of $\mathrm{p}^{*}$ that fits this specification.

The analysis above derived the critical value of Ep, denoted as $p^{\prime}$, that produced the highest value of $s_{t}$, given $p$ equal to Ep. Consequently, if $p^{\prime}$ is in the set of possible reputational 
equilibria, then $p^{*}$ equals $p^{\prime}$ Alternately, if $p^{\prime}$ is not in this set, $p^{*}$ is the member of this set closest to $p^{\prime}$. This result obtains because $s_{t}$ decreases monotonically as Ep diverges from $p^{\prime}$, given that inflationary expectations are validated.

Because $p^{*}$ is independent of $t$, the analyses can focus on period zero. As a member of the set of possible reputational equilibria, $p^{*}$ satisfies

$$
s_{0}^{*}>\bar{s}_{0}
$$

where $s_{0}^{*}$ is the value of $s_{0}$ that results from setting $p_{0}$ equal to $\mathrm{p}^{*}$ and $\overline{\mathrm{s}}_{0}$ is the value of $\mathrm{s}_{0}$ that would result from setting $p_{0}$ equal to $\bar{p}$. Substituting $p^{*}$ for $E p$ and $p$ in equation (5) yields

$$
\left.s_{0}^{*}=\exp \left(-\frac{p^{*}}{h}\right) \frac{1-\exp \left[-\tau\left(p+g^{*}\right)\right.}{1-\exp [-\tau(r-g)}\right]
$$

To calculate $\overline{\mathrm{S}}_{0}$, observe that, by setting $\mathrm{p}_{0}$ equals to $\overline{\mathrm{p}}$, the government obtains in period zero an amount of seigniorage given by

$$
\bar{s}_{0}=\exp \left(-\frac{p^{*}}{h} J\{1-\exp [-\tau(\bar{p}+g)]\}\right.
$$

At the same time this action causes the government to lose its good reputation. Consequently, future seigniorage, beginning in period one, corresponds to the result of Calvo's analysis. Thus, $\bar{s}_{0}$ equals the value of $S_{0}$ obtained by substituting $\bar{p}$ for both $E p$ and $p$ in equation (5), but with the component $s_{0}$ replaced by $\bar{s}_{0}$. This calculation yields 
$\bar{S}_{0}=\left\{\exp \left(\frac{-p^{\star}}{h}\right)+\exp \left(\frac{-\bar{p}}{h}\right) \frac{\exp [-\tau(r-g)]}{1-\exp [-\tau(r-g)]}\right\}\{1-\exp [-\tau(\bar{p}+g)]\}$.

To evaluate the implications of condition (8) for the value of $p^{*}$, observe first that

$\lim _{\tau \rightarrow 0} s_{0}^{*}=\left(p^{*}+g\right) \exp \left(\frac{-p^{*}}{h}\right)$, whereas

$\lim _{\tau \rightarrow 0} \bar{s}_{0}=(\bar{p}+g) \exp \left(\frac{-\bar{p}}{h}\right)$

Comparison of these limiting values, recalling also that $\lim _{\tau \rightarrow 0} \mathrm{p}^{\prime}=\mathrm{h}-\mathrm{g}$, and given that $\overline{\mathrm{p}}$ is larger than $\mathrm{h}-\mathrm{g}$, reveals that condition (8) is satisfied for $p^{*}$ equal to $p^{\prime}$. In other words, in this limiting case, the inflation rate $p^{\prime}$ is the reputational equilibrium.

This result obtains because, with continuous adjustment of real cash balances, the model of reputation given by equation (7) implies that by setting $p_{0}$ equal to $\bar{p}$ the government would cause an immediate reduction of real cash balances to the level associated with myopic behavior. Consequently, even though inflationary expectations are initially equal to $p^{*}$, the unanticipated inflation associated with setting $p_{0}$ equal to $\bar{p}$ would not produce any extra seigniorage even in the short run.

This experiment of allowing $\tau$ to approach zero, because it is equivalent to letting the demand for real cash balances in period $t$ depend on $E_{t} p_{t+l}$ rather than on $E_{t-l} p_{t+1}$, shows that a lag in either 
the perception of actual government behavior or in the adjustment of real cash balances is essential for explaining inflation rates in excess of $\mathrm{p}^{\prime}$. Remarkably, with $\tau$ equal to zero, the comparison of $\mathrm{s}_{0}^{*}$ and $\bar{s}_{0}$ does not involve $r$. Thus, $p$ ' would be the reputational equilibrium in this case no matter how high is the government's discount rate. (In this respect, the effect of unexpected inflation on seigniorage is fundamentally different from its effect on the real cost of servicing nominal debts that mature in the future. If the government's objectives included minimization of such real debt servicing costs, the reputational equilibrium for inflation would depend on the government's discount rate, even with no lags in perception or adjustment.)

Consider next the implications for condition (8), with a positive value of $\tau$, of allowing the maximum inflation rate, $\bar{p}$, to be very. large. Although the value of $s_{0}^{*}$ does not depend on $\bar{p}$, the specification of $\bar{s}_{0}$ implies

$\frac{1}{p \rightarrow \infty} \bar{S}_{0}=\frac{{ }^{M_{0}}}{p_{0}}=\exp \left(-\frac{p^{*}}{h}\right)$

In effect, by setting $p_{0}$ equal to $\bar{p}$, the government initially obtains as seigniorage the entire value of the initial real cash balances that the public holds on the presumption that the government is foresighted. Future seigniorage however, is zero. Accordingly, in this case condition (8) becomes $\frac{1-\exp \left[-\tau\left(\mathrm{p}+\mathrm{g}^{*}\right)\right]}{1-\exp [-\tau(\mathrm{r}-\mathrm{g})]}>1$, which is equivalent to $p^{*}+g>r-g$. 
In this case, $p^{*}$ equal to $p^{\prime}$ would imply $p^{\prime}+g>r-g$,

or, equivalently, from equation (6), $\frac{\ln (1+\tau h)}{\tau}>r-g$

Thus, with a positive lag in the adjustment of real cash balances, but with a very large value of $\bar{p}$, the Friedman answer for maximal seigniorage still is the reputational equilibrium if $p^{\prime}+g$ is at least as large as $\mathrm{r}-\mathrm{g}$. A high value of $\mathrm{p}^{\prime}+\mathrm{g}$, which implies a high value of $h$ and a low value of $\tau$, is important because it increases the amounts of future seigniorage associated with $p^{\prime}$ relative to the initial seigniorage associated with setting $p_{0}$ equal to $\bar{p}$. A low value of $\mathrm{r}-\mathrm{g}$ is important because it increases the importance of this future seigniorage relative to initial seigniorage in the present value calculation.

If $p^{\prime}+g>r-g$ does not hold, $p^{\prime}$ is not in the set of possible reputational equilibria. In that case, $p^{*}$ is the member of this set closest to $p^{\prime}$, and, thus, satisfies $p^{*}+g=r-g$. In sum, for positive values of $\tau$ and very large values of $\vec{p}$, the solution for $p^{*}$ satisfies

$p^{*}+g=\max \left(p^{\prime}+g, r-g\right)=\max \left[\frac{\ln (l-\tau h)}{\tau}, r-g\right]$

V. Summary and Extensions

An expected inflation rate in the set of potential reputational equilibria has the property that the present value of seigniorage is at least as large if the government validates this expectation as it would be if the government were to attempt to produce a temporarily 
large flow of seigniorage by making the inflation rate higher than the public expects. A foresighted seigniorage-maximizing government choses from this set the inflation rate that produces the highest present value of seigniorage. This inflation rate is the reputational equilibrium.

The above analysis derives the reputational equilibrium based on a model of reputation in which the public presumes that government behavior will be foresighted as long as the government has never behaved myopically. If, however, the government were ever to behave myopically, the public expects myopic behavior in the future. This expectation would eliminate or reduce possibilities for future seigniorage.

Given the model of reputation, the analysis derives two sufficient conditions under which the reputational equilibrium is the inflation rate that generalizes the Friedman elasticity solution to the maximal-seigniorage problem. One sufficient condition is that the public perceives actual government behavior contemporaneously and adjusts real cash balances immediately to new information. The other sufficient condition is that the government's discount rate does not exceed the growth rate of money demand by more than this inflation rate plus the growth rate. These conditions imply that, either if the effect of the potential loss of reputation is immediate or if the discount rate is low enough relative to other parameters, the government's concern for its reputation produces results that are isomorphic to Friedman's implicit presumption of irrevocable commitments. 
The analysis also shows that, given a lag in either perception or adjustment, a sufficiently large discount rate causes the reputational equilibrium for a seigniorage-maximizing government to be an inflation rate higher than the generalized Friedman elasticity solution. Specificially, if the generalized Friedman elasticity solution is not in the set of possible reputational equilibria, the reputational equilibrium is the inflation rate that, when added to the growth rate, exactly equals the difference between the discount rate and the growth rate. This inflation rate is the nember of the set of potential reputational equilibria that is closest to the generalized Friedman elasticity solution.

These results imply that different rates of inflation are associated with differences in the slope and growth of demand for real cash balances and with differences in the rate at which future seigniorage is discounted. One obvious extension of the analysis, along lines suggested by Friedman, would assume that, for whatever reason, the government is averse to a high expected inflation rate. This extension would rationalize the observation that actual inflation rates typically seem to be less than the reputational equilibrium implied by the single objective of maximizing seigniorage.

Another worthwhile extension would incorporate into the analysis reasons other than a desire for seigniorage that might tempt the government to try to make the inflation rate higher than the public expects. In a related analysis along these lines, Barro and Gordon (1983) analyse a reputational equilibrium for inflation that focuses on increasing aggregate employment and reducing the real cost of 
servicing the public debt as objectives of government policy. Adding these additional motivations for unexpected inflation to the above analyses would have the same effect as a longer lag in the adjustment of real cash balances or a larger discount rate for future seigniorge in raising the inflation rate that is the reputational equilibrium. A more ambitious extension of the analysis would be to model relevant parameters like the discount rate for future seigniorage as stochastic processes. This development would permit explicit analysis of variations in the inflation rate over time. 
REFERENCES

L. Auernheimer, "The Honest Government Guide to the Revenue from the Creation of Money," Journal of Political Economy, 82, May/June 1974 .

R. J. Barro, "Inflationary Finance and the Welfare cost of Inflation," Journal of Political Economy, 80, September/October 1972 .

R. J. Barro, "Inflationary Finance under Discretion and Rules," Canadian Journal of Economics, 16, February 1983.

R. J. Barro and D.B. Gordon, "Rules, Discretion and Reputation in a Model of Monetary Policy," Journal of Monetary Economics, 12, July 1983.

P. Cagan, "The Monetary Dynamics by Hyperinflation," in Studies in the Quantity Theory of Money, ed. M. Friedman (Chicago: University of Chicago Press, 1956).

G. Calvo, "Optimal Seigniorage from Money Creation," Journal of Monetary Economics, 4, August 1978.

S. Fischer, "Seigniorage and the Case for a National Money" Journal of Political Economy 90, April 1982.

M. Friedman, "Discussion of the Inflationary Gap," American Economic Review, 32, 1942; reprinted in Essays in Positive Economics (Chicago: University of Chicago Press, 1953).

M. Friedman, "Government Revenue from Inflation," Journal of Political Economy, 79, July 1971.

H. I. Grossman, "Counterfactuals, Forecasts, and Choice-Theoretic Modelling of Policy," NBER Working Paper No. 1381, June 1984.

D.A. Nichols, "Some principles of Inflationary Finance," Journal of Political Economy, 82, March/April 1974 . 
</ref_section> 